\title{
Key Concepts in Rhetorical Genre Studies: An overview
}

Natasha Artemeva

School of Linguistics and Applied Language Studies, Carleton University

Cet article fournit une vue d'ensemble complète de l'état actuel des études rhétoriques de Genre (RGS), également connu sous le nom de théorie nordaméricaine de genre. Elle suit le développement de RGS au cours des dernières vingt années avec une attention particulière payées aux tendances théoriques récentes. Ces tendances incluent un nouveau traitement théorique de l'aspect temporel du genre, qui accentue la nature dynamique du genre qui est contraignant et permettant pour un rhetor. Une autre tendance théorique qui suscite l'attention particulière est la nouvelle compréhension des genres surtout comme stratégies de communication flexibles. Ces tendances récentes dans le développement de RGS incitent des educators à reconceptualizer leur compréhension de ce qui rend la communication efficace et de ce qui est et n'est pas possible pour enseigner dans une salle de classe academique.

This article provides a comprehensive overview of the current state of Rhetorical Genre Studies (RGS), also known as North American genre theory. It follows the development of RGS over the past twenty years with particular attention paid to the recent theoretical tren. These trends include a new theoretical treatment of the temporal aspect of genre, which highlights the dynamic nature of genre that is both constraining and enabling for a rhetor. Another theoretical trend that receives special attention is the new understanding of genres as flexible communication strategies. These recent trends in the RGS development prompt educators to reconceptualize their understanding of what makes communication effective and what is and is not possible to teach in an academic classroom.

The reconception of genre as social action proposed by Carolyn Miller in 1984 provided a foundation for the development of a new discipline, Rhetorical Genre Studies (RGS). ${ }^{1}$ Unlike the traditional approaches to genre that view genres as stable text types characterized by their textual regularities, RGS considers genres as "typified symbolic actions in response to stock sets of situation types. Such a notion of 
genre allows for dynamism and change, given the inherent fluidity of the sociohistorical context to which genres respond" (Artemeva \& Freedman, 2001, p. 166). The new, rhetorical approach to genre conceives textual regularities as socially constructed (Miller, 1984/1994) and brings together "text and context, product and process, cognition and culture in a single, dynamic concept" (Paré, 2002, p. 57). RGS views genres as much more than simple organizers and regulators of human social activity (Bawarshi, 2000; Devitt, 1996, 2000; Miller, 1994a); genres are now seen as constituting human activity by "making it possible through its ideological and rhetorical conventions"(Bawarshi, 200o, p. 340).

This paper presents an overview of the development of Rhetorical Genre Studies over the past twenty years. Particular attention is paid to the new theoretical treatment of the temporal aspect of genre, the new understanding of genres as flexible communication strategies, and the pedagogical implications of Rhetorical Genre Studies. The overview starts by presenting a brief history of the development of the social rhetorical view of writing and Miller's reconception and redefinition of genre as social action. It continues by discussing the contribution made to RGS by Russian literary critic Mikhail Bakhtin, focussing on the key notions of addressivity and utterance and discussing the flexibility of speech genres. The overview proceeds with the new revised definition of genre proposed by Catherine Schryer (2000) and then introduces notions of genre sets and genre systems that allow researchers to look beyond a single genre. The sections that follow discuss the Bakhtinian notion of chronotope and its temporal qualities, including a discussion of notions of chronos and kairos; Anne Freadman's notions of textual and nontextual uptake; and rhetorical notions of community and identity of a rhetor. This paper concludes with a discussion of pedagogical implications of Rhetorical Genre Studies.

\section{The Development of the Social Rhetorical View of Writing}

The development of Rhetorical Genre Studies followed the rise and fall of the product-based and later process-based approaches in composition studies. The primary focus of the product-based approach, which dominated North American composition studies before the 1970s, was on the finished text. By the 1970 s researchers had recognized, however, that the singular focus on the final product could offer only a narrow view of writing that did not consider writers as in any way integral to the overall development of writing ability. This shift in the view of the writer's role in composing led to the emergence of the process approach that perceives the actual act of composing the text as the most important aspect of writing. However, the proponents of this approach continued to view writing as essentially a private, egocentric matter. 
Both these perspectives - the product and the process - failed to account for how social contexts influence meaning and affect the way a writer approaches a writing task (the process) and what he/she writes (the product). Gradually, it became clear that "writing and what writers do during writing cannot be artificially separated from the social-rhetorical situations in which writing gets done, from the conditions that enable writers to do what they do, and from the motives writers have for doing what they do" (Reither, 1985, p. 621). Due to the changing perception of the social aspects of the act of composing, writing began to be considered as located in the social world and, thus, to be fundamentally structured by the shape of the environment (Cooper \& Holzman, 1989).

A philosophic foundation for social and contextual perspectives on writing was provided by the work of Kenneth Burke (1957), Richard Rorty (1979), and Kenneth Bruffee (1986). A new emphasis on rhetorical context in composition studies has resulted in the emergence of a new approach that focusses on the social aspects of writing. This approach, known as the social view, began to dominate the area of composition studies by the 1980s (Cooper, 1989; Freedman \& Medway, 1994a). The social view perceives knowledge as socially constructed in response to communal needs, goals, and contexts (Freedman \& Medway, 1994a) and the composing of texts as part of the social process by which knowledge is constructed. A writer is seen as continually engaged with a variety of socially constituted systems and the discourse is viewed as "social, situated and motivated, constructed, constrained and sanctioned" (Coe, Lingard, \& Teslenko, 2002b, p. 2). The central questions for research grounded in the social perspective are those that concern the contexts in which texts are created. This rhetorical context view emphasizes that awareness of audience and purpose influences both what and how a writer writes (Barabas, 1990; Faigley, 1985; Freedman \& Medway, 1994c).

The theoretic shift toward the social in composition studies has been accompanied by a reconceptualization of genre as social action in response to recurrent rhetorical situations (Miller, 1984) perceived as a combination of purpose, audience, and occasion (Coe \& Freedman, 1998). Traditional approaches define genres as regular grouping of text types characterized by regularities in textual, that is, thematic, stylistic, and compositional, features, "irrespective of the historical conditions under which the types come to exist and of the social values attached to them in a given context" (Hanks, 1987, p. 670). Because of this focus on the texts themselves, rather than on the actions of the writers who produce them and the contexts in which they are produced, this concept of genre seems limited from the social perspective. As Swales (1993) notes, to understand how genres function "we need more socio-cognitive input than the text itself provides" (p. 690). The new approach to genre studies puts 
more emphasis on the rhetorical strategy, or to echo Coe et al. (2002b), on "the functional/motivated relation between form and situation" (p. 4). Genres in this view are defined as "the historically specific conventions and ideals according to which authors compose discourse and audiences receive it. In this view, genres consist of orienting frameworks, interpretive procedures, and sets of expectations that are not part of discourse structure, but of the ways actors relate to and use language" (Hanks, 1987, p. 670).

Rather than concentrating primarily on literary writing, as was the case with traditional genre studies, RGS has focussed more on the social dynamics and social constitution of nonliterary forms of writing and speaking. In other words, the main interest of the scholars conducting enquiry from the premises of RGS is to explore how and why non-literary - mostly workplace and academic - "typified texts reflect and reproduce social situations and activities.... how and why texts as cultural artifacts are produced; how they in turn reflect and help enact social actions; and how, finally, they can serve as sites for cultural critique and change" (Bawarshi, 2000, p. 336). The RGS scholars turned their attention to such texts as the experimental article, reports by tax accountants, student writing in content areas, engineering documents, business memoranda, government proposals, etc. (e. g., Artemeva, 1998, 2000; Beer, 2000; Berkenkotter \& Huckin, 1993, 1995; Freedman \& Medway, 1994a; Paradis, Dobrin \& Miller, 1995; Dias \& Paré, 2000; Paré \& Smart, 1994).

\section{Reconception and Redefinition of Genre: Genre as Social Action}

The new view of genre is based on Carolyn Miller's seminal article Genre as SocialAction (1984/1994), which, in its turn, is grounded in Kenneth Burke's New Rhetoric (1957) and especially his claim that discourse is action, and, in part, is based on the work of Campbell and Jamieson (1979). In 1979, Campbell and Jamieson proposed the view of genre that opened the path to the reconception of genre. They wrote,

If the recurrence of similar forms establishes a genre, then genres are groups of discourses which share substantive, stylistic, and situational characteristics. Or, put differently, in the discourses that form a genre, similar substantive and stylistic strategies are used to encompass situations perceived as similar by the responding rhetors. A genre is a group of acts unified by a constellation ${ }^{2}$ [italics added] of forms that recurs in each of its members. These forms, in isolation [italics in original], appear in other discourses. What is distinctive about the acts in a genre is the recurrence of the forms together [italics in original] in constellation. (p. 2o) 
The New Rhetorical approach to genre studies allows researchers to concentrate on the ways "particular discourses are socially motivated, generated, and constrained" (Coe \& Freedman, 1998, p. 137) and assists us in defining "the possibilities of meaning in discourse" (Hanks, 1987, p. 670). The distinguishing feature of the New Rhetorical inquiry is its focus on what discourse does. The New Rhetoric emphasizes discourse as primarily action - that is, its significance should be judged on the basis of what it does - and shifts emphasis away from discourse as representation, which is considered secondary (Coe \& Freedman, 1998; Coe, Lingard, \& Teslenko, 2002a). In other words, the New Rhetorical perspective on genre treats genre "as typified social action rather than as conventional formulas" (Devitt, 2000, p. 697). According to Jamieson (1975), "the question of the extent to which rhetorical response is determined by situation, audience expectations, antecedent rhetoric or other factor requires determined inquiry. It has no a priori answer" (p. 415).

\section{Rhetorical situation}

Reconceptualizing genre as a social action, Miller (1984) explored "how a [social] understanding of genre can help account for the ways we encounter, interpret, react to, and create particular texts" (p. 151) in response to a recurrent rhetorical situation, described by Bitzer (1968) as

a natural context of persons, events, objects, relations, and an exigence which strongly invites utterance; this invited utterance participates naturally in the situational activity, and by means of its participation with situation obtains its meaning and its rhetorical character. (p. 5)

While Bitzer identified a rhetorical situation as recurrent through a recognition of its similar material and perceptual components, Miller (1984) went beyond the material dimensions of this explanation and provides a social interpretation of "how genre represents 'typified rhetorical action' based on recurrent rhetorical situations" (p.151). In 1979, Campbell and Jamieson posed a question, "do comparable situations ever exist?" (p. 15). Miller's (1984) response to this question was,

What recurs is not a material situation (a real objective factual event) but our construal of a type. The typified situation, including typifications of participants, underlies typification in rhetoric. Successful communication would require that the participants share common types; this is possible insofar as types are socially created. (pp. 156-157) 
Miller argued that exigence is located in the social and is "a form of social knowledge - a mutual construing of objects, events, interests and purposes that not only links them but also makes them what they are; an objective social need.... It provides an occasion, and thus a form, for making public our private versions of things" ( $p$. 157). In other words, claims Miller, exigence is nothing else but "a socially objectified motive" (1984/1994a, p. 31), and "to comprehend an exigence is to have a motive" (p. 30). Exigence is seen as a defining factor for a rhetorical situation: as the one that shapes our recognitions of a social situation and the one that helps us to reproduce it. Exigence is not only part of our experience and our concept of a recurring situation but also part of our response to the situation (Bawarshi, 2000).

Miller (1984/1994a) notes that situations are "social constructs that are the result, not of 'perception,' but of 'definition.' Because human action is based on and guided by meaning, not by material causes, at the centre of action is a process of interpretation" (p. 29). Genre provides a rhetor with a rhetorical means "for mediating private intentions and social exigence; it motivates by connecting the private with the public, the singular with recurrent" (Miller, 1984/1994a, p. 37). The development of "recognizable genres" assists rhetors with "the recognition of situations as alike as recurrent" (Bazerman, 1997, p. 22). The rhetorical situation is thus seen as socially constructed and entailing exigencies that make demands on both the reader and the writer in their interaction with and through the text. By situating exigencies within the social, Miller's definition allows researchers to consider genre as extending beyond regularities in textual features. Genres in this interpretation are considered both rhetorical actions and recurrent situations (Paré \& Smart, 1994). That is, genres help rhetors to construct the very recurrent situations to which they rhetorically respond, or, to repeat after Bawarshi (2000), "we rhetorically recognize and respond to particular situations through genres because genres are how we socially construct these situations by defining and treating them as particular exigencies" (p. 357).

\section{Genres as textual instantiations of rhetorical situations}

In other words, while recognizing that genres can be characterized by regularities in textual form and substance, current thinking perceives these regularities as surface reflections of an underlying regularity. Genres play a key role in reproducing the very situations to which they respond. As Bawarshi (2000) puts it, genres constitute "their own social semiotic, a semiotic that rhetorically shapes and enables social actions and in turn is constituted by the very action which it enables. This is why genres shape our social realities and us as we give shape to them" (p.353). In this new perspective on genre, genres are less defined by their formal features than by "their purposes, participants, and subjects: by their rhetorical actions. Genre ... is defined 
by its situation and function in a social context" (Devitt, 2000, p. 698). Paré and Smart (1994) redefine genre as “a distinctive profile of regularities across four dimensions: a set of texts, the composing processes involved in creating these texts, the reading practices used to interpret them, and the social roles performed by writers and readers" (p.147). To sum up the new, rhetorical view of genre, Bawarshi (2000) describes genre as

both the situation and the textual instantiation of that situation, the site at which the rhetorical and the social reproduce one another in specific kinds of texts. Genre is [italics in original] what it allows us to do, the potential that makes the actual possible, the 'con' and the 'text' at the same time. As such genre allows us to study the social and the rhetorical as they work on one another, reinforcing and reproducing one another and the social activities, the roles, and the relations that take place within them. This recursive process is what genre is[italics in original]. (p. 357)

Anne Freadman (2002) expresses the essence of the new understanding of genre in the following words: "Genre is the capacity of human discourse that makes it different, say, from the language of the bees; that is what makes 'culture' a different matter from programmed instinct" (p. 41). Fundamental for the social constructionist view of genre is the work of Russian literary theorist, M. M. Bakhtin.

\section{Bakhtin: Utterance, Addressivity, and Flexibility of Genres}

Bakhtin's ideas have enhanced our understanding of the social embeddedness of genres (both oral and written) within communities of language users and, therefore, are central for understanding social aspects of writing process. Bakhtin (1986a) defines speech genres as "relatively stable types" (p. 60) of utterances, thus providing two useful concepts for understanding the nature of genre: the responsive utterance as the analyzable unit of speech (rather than the word or sentence) and the addressive nature of speech. For Bakhtin, the "responsive utterance" is the fundamental unit of analysis of human communication because it "occupies a particular definite [italics in original] position in a given sphere of communication" (1986a, p. 91). Words and sentences acquire meaning through the utterance. Describing an individual's speech (both oral and written) as always situated within the speech of others, he stresses the importance of recognizing the plurality of speakers in order to examine language use as communication (Hunt, 1994). Bakhtin sees an utterance as a link in a chain of discourse and points to its dual nature: any utterance simultaneously responds to 
past utterances while also anticipating future utterances. Bakhtin (1986a) highlights the importance of the presence of "the other" in language as well as the more specific awareness of a respondent in a communicative situation:

from the very beginning, the utterance is constructed while taking into account possible responsive reactions, for whose sake, in essence, it is actually created. As we know, the role of the others [italics in original] for whom the utterance is constructed is extremely great.... From the very beginning the speaker expects a response from them, an active responsive understanding. The entire utterance is constructed, as it were, in anticipation of encountering this response. (p. 94)

\section{Utterance}

In Bakhtin's view, words and sentences acquire meaning through the utterance, and speakers choose the generic form of the utterance which best meets their "speech plan or speech will" (p. 77). The dialogical principle of language that Bakhtin advocates presupposes the importance of addressivity, that is "the quality of being directed to someone" (p. 95). Without an addressee to whom an utterance is directed, it loses its dialogic context and turns into a separate statement belonging to nobody. Bakhtin suggests that addressivity is a constitutive feature of genre, noting that each genre "has its own typical conception of the addressee, and this defines it as a genre" (1986a, p. 95).

\section{Addressivity and dialogism}

Bakhtinian notions of dialogism ${ }^{3}$ and the addressivity of speech indicate the degree to which individual texts act as links between previous texts and the inevitable response of others. Miller (1994b) notes that addressivity allows an "individual communicative action and social system ... [to] interact with each other" (p. 71). Following Bakhtin's view of earlier utterances as something the speakers can draw upon while shaping their own utterance, Holquist (1990) interprets the relationship of the speaker and the other as the one of co-authorship (p.13). By bringing together Bakhtin's notions of otherness and dialogism, Holquist expresses the essence of dialogism: "In dialogism, the very capacity to have consciousness is based on otherness [italics in original].... in dialogism consciousness is [italics in original] otherness" (p. 18). Bawarshi (2000) responds to Bakhtinian notion of addressivity by asserting that "the speaker's very conception of the addressee is mediated by genre, because each genre embodies its own typical conception of the addressee. In fact, the very word and its relation to other words is also mediated by speech genres" (p. 348). The dialogic na- 
ture of speech, the necessity for a change of speaking subjects and respondents, the process of utterance exchange, all this reveals the communicative sense of oral language, and, according to Flower (1994) and others, "much the same thing is said to happen in writing" (p. 60).

Foreseeing the critics' reaction to his theory of speech genres as limiting a rhetor's creativity, Bakhtin (1986a) asserts that the better our command of genres, the more flexibility and freedom we can apply in using genres, "the more fully and clearly we reveal our own individuality in them ..., the more flexibly and precisely we reflect the unrepeatable situation of communication ..." (p. 80). Thus even acting recurrently in a recurrent situation, one can express one's individuality; that is, "creativity is possible and visible everywhere, although Bakhtin insists that 'genres must be fully mastered to be used creatively" (Freedman \& Medway, 1994C, p. 7 ).

\section{Primary and secondary genres}

Finally, Bakhtin introduces an important distinction between primary genres, which are most akin to forms of spoken communication, and secondary genres, more complex written forms. He refers to the relationships between these genres asserting that "primary genres are altered and assume a special characteristic when they enter into complex ones" (1986a, p. 62). Bakhtin (1986a) stresses that "genres are subject to free creative reformulation ... [but] to use a genre freely and creatively is not the same as to create a genre from the beginning" (p. 80). As Adam and Artemeva (2002) observe, redefinitions of genre based on Bakhtin's and Miller's views "recognize the plasticity and flexibility of texts and the rhetor's ability to reshape and manipulate genres to suit certain rhetorical situations" (p. 181). Rhetors acquire genres in the context of a situation and, therefore, genres can be "expertly used by speakers even though they may be unaware of generic parameters" (Hanks, 1987, p. 681). The central premise of Bakhtin's theory of genre as reiterated by Hanks (1987) is that "human consciousness ... comes into contact with reality only through the mediation of ideology ... and every genre has its own value-laden orientation" (p. 671). Hanks (1987) stresses that this "value-laden" quality of genre doesn't allow it to be viewed as a finished product; genres "remain partial and transitional. The actuality of discourse changes with its reception, and social evaluation is always subject to revision" (p. 681). Genres involve both form and content which are inseparable. The form of discourse in the field changes along with the changing intellectual content. As Freedman and Medway (1994c) state, "particularly significant for North American genre studies has been Bakhtin's insistence that ... generic forms 'are much more flexible, plastic and free' (1986a, p. 79) than grammatical or other linguistic patterns" (p. 6). Far from being rigid templates, genres can be modified according to rhetorical circumstances 
(Berkenkotter \& Huckin, 1995). In Miller's (1984) words, genres evolve, develop, and decay. Miller (1994b) observes that the shared knowledge that allows individuals to be engaged in a competent communication "includes structures of interaction, of exigence, of participant roles, and of other rules and resources. Genres ... help do our rhetorical thinking for us" (p. 72).

The reconception of genre has led to the changes in the focus of genre studies, which in turn led to further development of the field of Rhetorical Genre Studies. Within the framework of RGS, genres are viewed as situational expectations. A complete description of a genre from the RGS perspective "requires attention to how the form is rhetorical, to how it embodies the type of recurring situation that evokes it, and how it provides a strategic response to that situation" (Coe et. al., 2002b, p. 6). In other words, genre is a concept that accounts for the ways all types of discourse function in the world, for the social roles assigned to various discourses, and for "the mode of being of those who participate in the discourse" (Bawarshi, 2000, p. 339). Within the framework of Rhetorical Genre Studies, genres are seen as types of discourse originating from "the interplay between systems of social value, linguistic convention, and the world portrayed. They derive their practical reality from their relation to particular linguistic acts, of which they are both the products and the primary resources" (Hanks, 1987, p. 671).

\section{Schryer's Revised Definition of Genre}

Schryer (1999), following Jamieson (1975), finds that genres have simultaneously diachronic and synchronic relations; that is

genres have complex sets of relations with past and present text-types: genres come from somewhere and are transforming into something else. Genres, because they exist prior to their users, shape their operators; yet their users and their discourse communities constantly remake and reshape them. (p. 81)

Schryer makes an important observation that genres are stabilized-for-now or stabilized enough sites of social and ideological action $(1993,1994)$ and asserts that genres are constantly changing in response to changing exigencies and, therefore, changing rhetorical situations. However, Devitt (2000) argues "that genres are never really stabilized. If each text always participates in multiple genres, then even in that text a genre is moving, shifting, and becoming destabilized. Even temporary stability is an illusion of genre theory rather than a reality of genre-in-action" (p. 713). Genres are not simple tools that rhetors use to deal with the situations that are already familiar with; "rather, situations and their participants are always in the process of reproduc- 
ing each other within genre" (Bawarshi, 2000, p. 354). Schryer $(1995,2002)$ goes further and proposes to use "genre" as a verb: we genre our way through social interactions, choosing the correct form in response to each communicative situation we encounter - and we are doing it with varying degrees of mastery. At the same time "we are genred" (Schryer, 2002, p. 95) all the time; that is, we are socialized into particular situations through genres.

Schryer $(2000,2002)$ proposed a revised definition of genre grounded in Campbell and Jamieson's 1979 work Form and genre in rhetorical criticism: An introduction. Campbell and Jamieson use a constellation metaphor ${ }^{4}$ as the basis of their view of rhetorical genre: "a genre is composed of a constellation of recognizable forms bound together by an internal dynamic" (p. 21). They assert that "an understanding of the genre as a fusion of elements, formed from a constellation of forms, permits one to distinguish between classification and generic analysis" (p. 23) and continue by saying that

the term 'constellation' suggests another metaphorical insight. The stars forming a constellation are individuals but they are influenced by each other and by external elements; consequently they move together and remain in a similar relation to each other despite their varying positions over time. Like genres, constellations are perceived patterns with significance and usefulness - they enable us to see the movements of a group of individual stars and they enable us to understand the interrelated forces in celestial space. (p. 25)

Building upon the notion introduced by Campbell and Jamieson in 1979, Schryer (2000) redefines genres as "constellations of regulated, improvisational strategies triggered by the interaction between individual socialization ... and an organization" (p. 450 ). Schryer (2000) explains that the term constellation allows her " to conceptualize genres as flexible sets of reoccurring practices (textual and nontextual)" (p. 450), while the term strategies allows her "to reconceptualize rules and conventions (terms that seem to preclude choice) as strategies (a term that connotes choice) and thus explore questions related to agency" (p. 451). Coe (2002) adds that genre is "the motivated, functional relationship between text type and rhetorical situation" (p. 198).

Recently, attention of genre researchers has shifted from the analysis of single genres to groups of connected genres and to "the relationships among genres within a community" (Yates \& Orlikowski, 2002, p. 103). 


\section{Sets and Systems of Genres}

Genre theorists have acknowledged that, even though analyses of individual genres provide us with information necessary for the understanding of community norms, practices, and ideologies, it is impossible to unpack complex communicative phenomena without studying interactions among genres (Devitt, 2000; Yates \& Orlikowski, 2002). Bazerman (1994) suggests that within each specific setting, a limited range of interrelated genres "may appropriately follow upon another" (p. 98) affecting other genres that follow in response to a specific situation. He states that in response to a typified situation, rhetors must act generically in order for others to recognize and accept their act, which would not be possible "without a shared sense of genre" (p. $100)$. However, considering singular texts produced in response to rhetorical context may limit our understanding of the complexity of generic interaction and the ways in which some genres call for other genres (Devitt, 2000). In one and the same social situation, usually, more than one genre is used, and "each genre within a situation type constitutes its own ... particular social activity, its own subject roles as well as relations between these roles, and its own rhetorical and formal features" (Bawarshi, 2000, p. 351). Devitt (2000) observes that in order to understand how a genre functions, it is necessary to understand all the other genres that surround and interact with the one under consideration, both the ones that act explicitly and the ones whose existence is only implied.

\section{Genre sets}

Over the past ten to fifteen years various concepts describing interaction among genre have been proposed. Thus, in her study of tax accountants' work, Devitt (1991) introduced the notion of a "genre set." A genre set represents all types of texts produced by a person in a particular occupation in the process of his/her work. The concept of genre repertoire proposed by Orlikowski and Yates (as cited in Yates \& Orlikowski, 2002), as well as Devitt's genre set, refer to the groups of genres routinely used by members of a particular community. However, according to Bazerman (1994), it is crucial to understand that generic texts "have highly patterned relationship with the texts of others .... The genre set represents ... only the work of one side of a multiple person interaction" (p. 98). Bazerman (1994) extends the notion of genre sets proposing to overcome its limitations by introducing the concept of the system of genres that encompasses a full set of "interrelated genres that interact with each other in specific settings" (p. 97) and represents 
full interaction, the full event, the set of social relations as it has been enacted. It embodies the full history of speech events as intertextual occurrences, but attending to the way that all the intertext is instantiated in generic form establishing the current act in relation to prior acts. (p. 99)

\section{Genre systems}

Bazerman's concept of genre systems (1994) goes beyond the local community or professional organization context and addresses connected genres produced as a result of consequential social action within the same activity "enacted by all parties involved" (Yates \& Orlikowski, 2002, p. 103), from both within and without a particular organization or community. Bazerman (1994) suggests that members of the communities involved in an activity create "a complex web of interrelated genres where each participant makes a recognizable act or move in some recognizable genre, which then may be followed by a certain range of appropriate generic responses by others" (pp.96-97). This concept reflects a complete communicative interaction including all social relations and the history of the interaction.

In 1979, Campbell and Jamieson observed that a rhetorical genre theory would allow rhetoricians to move beyond separate individual events limited by time and place and explore similarities of rhetorical actions across time. The concept of chronotope developed by Bakhtin (1981) and absorbed into RGS provides us with this opportunity.

\section{Bakhtinian Notion of Chronotope}

Bakhtin introduces the dimension of time-space, which he calls the chronotope, in Forms of time and of the chronotope in the novel: Notes towards a historical poetics (1981). Following Bakhtin, Michael Holquist (1981) provides the following succinct definition of the chronotope: "a unit of analysis for studying texts according to the ratio and nature of the temporal and spatial categories represented.... neither category is privileged, they are utterly interdependent" (p. 425). Bakhtin stresses that in his definition of chronotope, time is inseparable from space; that is, temporal and spatial relationships are intrinsically connected.

Even though the notion of unified time-space (or spacetime) as a dimension of the human universe has been used in other disciplines (e.g., in mathematics by Minkovski; in biology by Ukhtomskyi, and in physics [relativity theory] by Einstein), Bakhtin (1981) makes a clear distinction between the use of the term in hard sciences and in his literary theory ${ }^{5}$ : 
The special meaning [time-space] has in relativity theory is not important [italics added] for our purposes; we are borrowing it for literary criticism almost as a metaphor (almost but not entirely). What counts for us is the fact that it expresses the inseparability of space and time (time as the forth dimension of space). We understand the chronotope as a formally constitutive category of literature; we will not deal with the chronotope in other areas of culture. (p. 84)

Bakhtin (1981) explains that "it is precisely the chronotope that defines genre and generic distinctions" and adds that "the primary category in the chronotope is time" (p. 85). He says, "everything - from an abstract idea to a piece of rock on the bank of a stream - bears the stamp of time, is saturated with time, and assumes its form and meaning in time.... Everything in this world is a time-space, a true chronotope [italics in original]" (1986b, p. 42); that is, genres regulate how readers and writers "spatially negotiate ... [their] way through time" (Bawarshi, 2000, p. 346).

When Bakhtin analyzes chronotopes of various types of novel, he demonstrates that in some chronotopes (for example, in the literary chronotope of the Greek Romance "adventure novel of ordeal"), "an individual can be nothing other than completely passive, completely unchanging.... to such an individual things can merely happen [italics in original]. He himself [sic] is deprived of any initiative" (1981, p. 105), while in other chronotopes (as in the Greek "adventure novel of everyday life"), the primary initiative belongs to the individual character.

Schryer $(1999,2002)$ further extends Bakhtin's definition of the chronotope by stressing its axiological quality and stating that the notion of the chronotope expresses the connectedness of not only place and time but also human values and current social beliefs. She $(1999,2002)$ stresses that in each chronotope differing sets of values are attributed to individual agents and, therefore, individuals in some chronotopes have more access to meaningful action and power than in other chronotopes. She insists that when we explore the relationship between genre and power we need "to explore its relationship to time, not just in form of its relationship to the past, present, or future ... [but also] in terms of a genre's attempt to control time/space by defining what categories of time/space are at work within specific genres and accepted as just common sense" (1999, pp. 81, 84). To understand the rules of genres and use them properly means "to know when and where it is appropriate to do and say certain things, and to know that to do and say them at inappropriate places and times [emphasis added] is to run the risk of having them ruled out" (Freadman, 1994, p. 59); in other words, our knowledge of genres is inseparable from our understanding of the 
chronotope. Schryer (2003) also asserts the need to explore "the possibilities for human action" in different chronotopes and "genre's relationship to time and space" (p. 76) within these chronotopes.

Schryer (1999) notes that Bakhtin's view of "the relationship of discourse to space and time" is characterized by the three key terms that he has introduced: dialogism, genre, and the chronotope (p. 82). Holquist (1990) further links the concepts of dialogism and chronotope by explaining that

all meaning is relative in the sense that it comes about only as a result of the relation between two bodies occupying simultaneous but different space [italics in original], where bodies may be thought of as ranging from the immediacy of our physical bodies, to political bodies and to bodies of ideas in general (ideologies). (p. 20)

In his concluding remarks to Forms of time and of the chronotope in the novel: Notes toward a historical poetics (1981), written much later than the article itself, ${ }^{6}$ Bakhtin asserts the representational importance of the chronotope. He states that time is materialized in the space through the chronotope and thus, "the chronotope [is] ... a centre for concretizing representation" (p. 250). He restates the crucial role of the chronotope as a "conductor" of meanings through which they enter humans' social experiences. In other words, Bakhtin says that meanings

must take on the form of a sign [italics in original] that is audible and visible for us (a hieroglyph, a mathematical formula, a verbal or linguistics expression, a sketch, etc.). Without such temporal-spatial expression, even abstract thought is impossible. Consequently, every entry into the sphere of meanings is accomplished only through the gates of the chronotope. (p. 258)

In Freadman's words (1994), "Meaning is not content; it is place and function" (p. 59). Schryer (1999) further explains the interconnectedness of the communication of meaning in discourse, dialogism and the chronotope, stating that first, "in dialogism all discourse is located, and the notion of an objective observer outside of place and time is impossible. Secondly, in dialogism simultaneity is a necessity. Participants are in a constant state of openness to time, to the present" (p. 82). The exchange of meaning, "or point of temporary stability is possible only if the participants have access to shared categories or concepts. So the other [italics added] must be present either metaphorically or actually for events and for the participants to acquire meaning" (p. 82). In other words, "communication is, ultimately, about creating shared time" (Fabian; as cited in Schryer, 1999, p. 85). Genre is a constituent of society that largely defines its 
communicative structure should be seen "as that aspect of situated communication that is capable of reproduction [italics in original], that can be manifested in more than one situation, more than one concrete space-time [italics added]" (p.71).

With this new focus on time and space, their role in the development, use, and recognition of genres within various chronotopes and the analysis of specific temporal and spatial notions becomes particularly useful.

\section{Chronos and Kairos as Two Types of Time}

Two ancient Greek notions that reflect different qualities of time are chronos and kairos. Kairos can be defined as "the right time," "the right moment" or "the opportune"; that is, the qualitative, experiential aspect of time, while chronos is a measurable, quantitative, calculable and repetitive aspect of time that "designates the continuous flux of time"7 (Definition of Kairos, n. d.; Miller, 1992). In other words, kairos points to a significant, unique moment of time. The word "timing," that is, doing something at the right moment, characterizes the meaning of kairos best (Definition of Kairos, n. d.). Kairos is "a rhetorical combination of understood context and proper timing" (Doherty, n. d.) or as Tillich defined it, a "crisis' or 'fullness of time, the right time for creative thought and action" (Sessions, 1995, p. 803).

However, the two meanings of the word kairos, that is "the right moment" or "the opportune," give rise to the key question that needs to be resolved before the notion of kairos can be productively used in Rhetorical Genre Studies: is kairos objectively given or constructed by humans?, or, in other words, "is the rhetor recognizing [italics added] the kairos of the situation, or creating [italics added] it?" (Doherty, $n$. d.). Yates and Orlikowski (2002) propose an interpretation of kairos that follows the "third" perspective offered by Miller (1992). This perspective recognizes the "dynamic interplay between objective and subjective, between opportunity as discerned and opportunity as defined" and sees kairotic opportunities as both "constructed as well as discovered" (Miller; as cited in Yates \& Orlikowski, 2002, p. 109). Therefore, Yates and Orlikowski (2002) interpret kairos as both "emerging [italics added] from the communicative activities of human actors (i.e., rhetors and audiences) in specific situations (e.g., institutional context, task, place, and chronological [italics in original] time)" and as "enacted [italics added], arising when socially situated rhetors choose and/or craft an opportune time to interact with a particular audience in a particular way within particular circumstances"(p. 108). Yates and Orlikowski further suggest that we should focus on notions of chronos and kairos "to help us think about issues of time and timing in genre systems[italics added]" by concentrating "our attention on active shaping of kairotic moments rather than passive acceptance of the chronological ones" (p. 118). 
Yates and Orlikowski (2002) see Bazerman's concept of genre systems as directly connected to the notion of the chronotope, that is, "situated in the interconnected nexus of time-space" (p. 107). Genre systems provide temporal and locational expectations for the system itself as well as all genres that constitute the system. That is, the genre system "may be seen to coordinate or choreograph a multiparty interaction within the community. It serves as a template or schematic representation of the interaction that participants ... draw on in accomplishing this interaction" (p. 107). Yates and Orlikowski see the sequencing of genres as part of the temporal aspect of the system's chronotope and suggest that this sequencing may be understood in terms of kairos, which plays a central role in "the enactment of genre systems" (p. 110). That is, the notions of kairos and chronos can help us to understand the timing and sequencing of the genre system and its constituent genres and to uncover how individuals coordinate activities by tacitly using or deliberately shaping kairotic time. Kairotic coordination (the orchestration of communicative activities within communities [Bazerman; as cited in Yates \& Orlikowski, 2002])

can be seen both to emerge from participants' enactment of a genre system and to shape that enactment as participants situate the communicative action within a particular time and place. Chronologicallitalics in original] time serves as one resource upon which participants may draw in focusing other participants' attention and thus coordinating their communicative activities. This resource, like others that participants draw on in acting, both constrains and enables those activities. (p. 110)

Miller (1994b) notes that "genre becomes a determinant of rhetorical kairos (emphasis in the original) - a means by which we define a situation in space-time and understand the opportunities it holds" (p. 71). Schryer (2002) indicates that agents within a particular social setting may become habituated to genres - or, in her definition, to the constellations of communicative strategies - and may "fail to see the possibilities for the constraints on human action that they enact" (p. 85). Under such circumstances the agent's ability to create or seize a kairotic moment in the flux of chronological time may become impeded by the constraining features of genre.

The view of genre that includes the understanding of its chronotopic and, in particular, temporal qualities highlights its dynamic nature that is both constraining and enabling for a rhetor. The rhetorical view of genre allows us to uncover the recursive nature of the connection between genre and exigence within a particular chronotope. However, this view may lead to certain oversimplifications if we define genres "only as the typified rhetorical ways in which individuals function within socially defined and a priori recurrent situations" (Bawarshi, 2000, p. 356) within a par- 
ticular time/space. To avoid this simplification, Anne Freadman in her articles Anyone for tennis? (1994) and Uptake (2002) introduces the notion of uptake borrowed from speech act theory.

\section{Notions of Uptake and the Nontextual Part of the Utterance}

\section{Uptake}

Freadman (2002) defines uptake after Austin: “'Uptake' is what happens when you accept an invitation to a conference, or agree to rewrite a paper for publication (and erase the traces of its previous occasionality for that purpose), or disagree with, or explore, a proposition in theory" (p. 39). She introduces the notion of uptake in order to highlight that "important issues of genre arise at the point of interaction between texts" (Coe et al., 2002b, p. 7).

Freadman proposes to use the concept of a game to facilitate our understanding of genres and uses the game of tennis as an example. She says that we do not learn "the content" of a game first and then learn its rules; rather "a game - and likewise a genre - is constituted [italics in original] by its rules and the techniques for implementing them" (1994, p. 46). A text in this view is considered a move in a game, and each move expects an uptake. In Freadman's (1994) view, the playing of a game constitutes what she calls "a ceremony" (p. 46), and the ceremony includes not only the game but all activities surrounding it: preparation, the choice of partners, occasion, location, timing, the warm-up, the declaration of a winner, and closing rituals. Or, in other words, she says, "ceremonies are rules for playing, games are rules for play" (p. 46). Continuing with the tennis metaphor, Freadman notes that it is useful to consider each game, that is, each genre, as consisting, minimally, either of two texts, or of a text and a nontextual response, in a dialogical relation. ${ }^{8}$ In other words, "genre is governed by a ceremonial sequence in a formalized space and time [italics added]" (Coe et al., 2002b, p. 7) that is enacted by appropriate persons to cause a specified outcome. It is important, however, to bear in mind that the two texts constituting one genre in Freadman's view, or a text and its nontextual uptake, will have different properties, like, for example, a question and an answer.

\section{Nontextual utterance}

The notion of a nontextual utterance had been mentioned in the literature before Freadman used it in her theoretical treatment of uptake. Thus, for example, textual as well as nontextual utterance, or uptake, were discussed as early as in 1930 by Voloshinov (1930/2000) who analyzed the notion of vneslovesnaya (podrazumevaemaya) chast' viskazivaniya (the non-verbal [implied)] part of the ut- 
terance) $(1930 / 1983)^{9}$, noting that "every utterance is composed in effect of two elements: a verbal and a non-verbal part [italics in original]" (p.124). He uses an example of an interaction between two individuals, in which one says "Hm..." and the other, in response, blushes and leaves, and then provides several different scenarios in which this interaction becomes fully meaningful in different, but typified and recognizable, ways. Voloshinov (1930/1983) proposes that we consider three main factors that affect the non-verbal component of the utterance: "the time and place of the event of the utterance (the 'where' and 'when'); the topic or theme of the utterance ('what' is being spoken about); and the speakers' attitude [italics in original] to what is happening (the 'evaluation')" (p. 125). By introducing these three factors, he inextricably links the meaning of the non-verbal (nontextual) part of the utterance to the chronotope of a particular situation. Schryer (2000) reasserts the equal importance of textual and nontextual communication practices that comprise genres. It is important for our understanding of the notion of uptake that we realize the equal importance of the textual and nontextual parts of the utterance and accept that a textual "tennis shot" may be taken up non-textually.

In Anyone for Tennis? (1994) Freadman proclaims that what is most important about our knowledge of genres is our knowledge of the difference between genres. As Devitt (2000) puts it genres need to be understood in terms of what genres are and what they are not. We never occupy a chronotope that is devoid of genres: as Freadman (1994) puts it, "we never leave the space of rituals for a space of non-rituals: we choose one ritual instead of another" (p. 61). Freadman continues by saying that "knowing a genre [that is, being able to carry out a task effectively] is also knowing how to take it up" (p. 63) and understanding its time and place (the chronotope). However, it also includes the understanding that genres do not exist independently. A genre "arises to complete or to contrast with other genres, to complement, augment, interrelate with other genres.... A genre, therefore, is to be understood in relation to other genres, so that its aims and purposes at a particular time are defined by its interrelation with and differentiation from others genres" (Devitt, 2000, p. 700). Schryer (2002) insists that while conducting a genre analysis, researchers should bear in mind that the recurrence of a specific rhetorical situation to which a genre or a genre system is a typified response may be identified only by "the social actors involved in that social setting" (p. 77). Understanding relationships of the social actors within a community becomes, therefore, one of the key issue of Rhetorical Genre Studies. 


\section{The Notion of Community in Rhetorical Genre Studies}

As this overview of Rhetorical Genre Studies has shown, genres can be fully mastered only by insiders of a particular community and are best understood in action. This concept can be considered as the basis for the emergence of the notion of discourse community that has become one of the key notions of modern social constructionist genre theory.

\section{Discourse community}

Swales (1990) made an important contribution to rhetorical genre theory by suggesting that genres are located within their discourse communities. According to Swales, discourse communities develop, use, and modify written genres in response to the recurrent rhetorical situations they face. Swales (1990) presents a fully developed notion of discourse community as a construct which provides insight into the "sociorhetorical" activities of groups. These groups communicate their norms and values and conduct their affairs through the appropriation and use of particular forms of discourse.

The usefulness of the concept of discourse community has come under some criticism because of the difficulty of defining it in any precise way and because of certain implications it seems to have accumulated (Dias et al., 1999; Harris, 1989). The term community suggests a kind of harmony that seldom exists in the real world and thus can prevent researchers from seeing that multiplicity and diversity must exist in any group (Williams, 1976). Moreover, the idea that disciplines may use language in ways unique to them has sometimes been interpreted to mean that there is a set of external rules that a newcomer can simply study and learn (Dias et al., 1999). Thus the discourse community may be seen as replacing the grammar handbook as a source of guidelines for good writing. Devitt (1996) notes that Rhetorical Genre Theory "needs to heed the criticisms of discourse community as homogeneous, without conflict and tension and examine how genre theory can acknowledge conflict and diversity as an important part of genre" (p. 613).

Swales himself (1993) admits that he was "too easily seduced by the concept of discourse community" (p. 694) and continues to say that "the 'true' discourse com munity may be rarer and more esoteric than I once thought" (p. 695). He goes on to observe that individuals simultaneously belong to multiple communities that require command of distinct genres used in response to dissimilar situations and questions the kind of discourse community that exists through membership and collectivity. An alternative notion was proposed by Parks and Maguire (1999) in their study of acculturation of a francophone nurse at an Anglophone hospital: the notion of community of discursive practice (p. 152). However, this notion is not developed by the 
authors. Swales suggests that in the light of critique of the notion of discourse community, we may want to turn to another view of community, the one that Carolyn Miller (1994b) introduces as an entity internal to rhetoric, "a virtual entity, a discursive projection, a rhetorical construct. It is the community as invoked, represented, presupposed, or developed in rhetorical discourse.... Like genres, rhetorical communities 'exist' on a discursive hierarchy, not in space-time; they exist, however, at a much higher level of cumulation than genres" (p.73). Carolyn Miller asserts that many genre researchers have been looking for communities as groups either unified demographically or geographically (e.g., classrooms, civic task forces, hobby groups, academic conferences, and so on). The rhetorical community, as Miller (1994b) calls it, "works in part through genre ... as the operational site of joint, reproducible social actions, the nexus between private and public, singular and recurrent, micro and macro" ( $p$. 73) and "it is this inclusion of sameness and difference, of us and them ... that makes a community rhetorical, for rhetoric in essence requires both agreement and dissent, shared understanding and novelty .... In a paradoxical way, a rhetorical community includes 'the other"' (p. 74). The rhetorical community does not have the same comfortable and homogeneous qualities as Swales' discourse community-Miller characterizes it "as fundamentally heterogeneous and contentious" (p. 74).

\section{Communities of practice}

However, recently, social theorists of learning and practice (Lave \& Wenger, 1991; Wenger, 1998) have proposed other, more refined concepts, for example, the concepts of communities of practice and learning communities. As Dias et al. (1999) claim, the term “'communities of practice' despite the problematic term 'community' ... [is] both more general, in that it covers activity beyond language, and more precise, since it centers on what groups of people do[italics in original]" (p. 29). For communities of practice, "learning is not a separate activity. It is not something we do when we do nothing else or stop doing when we do something else" (Wenger, 1998, p. 8). The notion of communities of practice allows one to see learning "that is most personally transformative ... to be the learning that involves membership in these communities of practice" (Wenger, 1998, p. 6). Each community of practice is constituted by distinct intellectual and social conventions. These conventions are shared assumptions about the roles of the audience and the writer and the social purposes for communicating. Writing in a domain-specific course in an academic setting can be used as a means of acquiring domain-specific genres (that is, learning such intellectual and social conventions), thus giving students the occasion "to use the lines of reasoning of a disciplinary forum to resolve issues important to that forum and to assume the role of a participant in that forum" (Herrington, 1985, p. 405). 
This discussion of community as one of the central RGS notions would be incomplete without a discussion of the formation of a professional identity in novices entering professional communities of practice.

\section{The Notion of Identity in Rhetorical Genre Studies}

The notion of identity is particularly important for RGS because genre "is largely constitutive of the identities we assume within and in relation to discourse" (Bawarshi, 2000, p. 343). Bazerman (2002) notes that over the past ten to fifteen years multiple studies of the development and formation of identities through participation in systems of genres have been conducted. These studies have demonstrated that social action and identity construction are both mediated through genre and constituted by genres (Hirsh; as cited in Bawarshi, 2000, p. 343). Genres provide social codes of behavior for both interlocutors (the speaker and the listener, the writer and the reader) involved in a dialogic exchange (Bawarshi, 2000; Voloshinov, 1930/1983). Particularly important in the recent literature on RGS is the formation of a professional identity of a novice who moves into the workplace after years of academic and professional training. Paré (2002) defines this move "into the professional persona [as] ... an ideological transformation that occurs through participation in workplace genres" ( $p$. 66). The development of a professional identity is inextricably linked to participating in workplace genres and "learning one's professional location in the power relations of institutional life" (p. 69). From this perspective, identity formation is linked to socialization into, the resistance to or subversion by local genres, which may occur either without one's conscious involvement or through a critical analysis of a chronotope of an organization. It is our goal as educators to prepare our students for such analyses of the chronotopes, situations, and communities they will become part of upon leaving academe.

Bazerman (2002) discusses the interconnectedness of genre acquisition and the development of an identity linked to a particular experience and activity. He observes that individuals become committed to the identities they develop through participation in genres of a particular community, and "in these ways genre shapes intentions, motives, expectations, attention, perception, affect, and interpretive frame" (p. 14). Lave and Wenger (1996) introduce the notion of a knowledgeably skilled identity, which, as Smart and Brown (2002) observe, is closely linked to a growing sense by novices of professional competence. Learning to communicate in a particular professional situation is part of the process of becoming a legitimate member of a particular community of practice. As Dias et al. (1999) and Smart and Brown (2002) have observed, learning to become an accepted and functioning member of a particular workplace situation does not involve a simple transfer of knowledge and skills acquired in an 
academic setting directly to a professional setting. Smart and Brown (2002) note that a growing sense of a novice as a competent professional, that is, the development of the professional identity, contributes to the novice's ability to act as an expert and enhances his/her capacity to learn in the workplace.

These key notions developed within the framework of RGS and reviewed above have important implications for pedagogy.

\section{The Pedagogical Implications of RGS}

The rhetorical view of genre reviewed in this paper allows us to analyze university writing by studying the contexts in which it has been created in the writers' roles as students rather than through comparing it to writing produced by accomplished writers (Bawarshi, 2000; Parks \& Maguire, 1999). Miller (1994a) makes the following point:

what we learn when we learn a genre is not just a pattern of forms or even a method of achieving our own ends. We learn, more importantly, what ends we may have [italics added] .... We learn to understand better the situations in which we find ourselves and the potential for failure and success in acting together. As a recurrent, significant action, a genre embodies an aspect of cultural rationality .... for a student, genres can serve as keys to understanding how to participate in the actions of a community. (p. 38)

If we as educators subscribe to Miller's perspective on learning genre, it is only logical for us to agree that teaching genre conventions of workplace genres in a classroom is useless at best. Freedman $(1993,1994,1999)$ strongly cautions educators from falling into the trap of teaching textual features and conventions of genres out of the natural context in which these genres occur and asserts that only in some situations, explicit indication of certain genre conventions may be to some extent helpful to students. Anne Freadman (1994) agrees that the teaching of linguistic forms does not result in the production of appropriate texts. She uses her notion of the ceremonial with its chronotopic qualities (locational and temporal) and the notion of nontextual uptake to underscore that language interacts with multiple semiotic systems to form texts, and that the linguistic forms, or textual conventions of genre, are derived from all these semiotic systems and the chronotope of the situation.

RGS scholars (e.g., Berkenkotter \& Huckin, 1993, 1995; Dias \& Paré, 2000; Dias et al., 1999; Freedman, Adam, \& Smart, 1994; Parks \& Maguire, 1999) base their understanding of genre on the notion of situated learning (Lave \& Wenger, 1991) and define genre as situated, "derived from and embedded in our participation in the communi- 
cative activities of daily and professional life'" (Devitt, 1996, p. 610). Therefore, as Anne Freadman (1994) cautions, even if we teach a range of interconnected semiotic systems that form any genre, "it would also be wise not to confuse the recipe with the rules of place and appropriateness, nor constitutive rules with regulative rules" ( $p$. 63).

Bringing together recent developments in RGS and complementary theories, Adam and Artemeva (2002) summarize important characteristics of genre and genre acquisition as follows:

1) genres arise out of and reflect rich discursive environments;

2) in addition to distinctive textual features, genres are characterized by distinctive composing and reading practices, as well as social roles of parties involved;

3) rhetors' knowledge of genres is largely tacit, even, or especially, for expert genre users (e.g. writers and speakers);

4) an individual's ability to "genre" (Schryer, 1995, 2002) in a community is almost always a necessary part of her socialization/acceptance into a community, and

5) people learn to use genres (at home, in the community, in classrooms, at work) very often without explicit instruction. (p. 183)

This last point is important because it dramatically changes perceptions of how genres are learned and taught. RGS provides us with a new and radically different perspective on genre learning as opposed to the traditional view that genres (that is, their textual features) can and should be explicitly taught in the classroom.

Explicit teaching of genre features ${ }^{10}$ and the dangers of creating simulations in the classroom and trying to teach genres through simulated tasks have been fully discussed in the RGS literature (e.g., Freedman, 1993, 1994, 1999; Freedman \& Artemeva, 1998). As Anne Freadman puts it, "the use of simulation techniques in the ceremonial frame of 'straight' classroom practice subverts the simulated game: its stakes are no longer at stake; the stakes of playing are those of playing the usual work for marks and teacher's feedback game" (p. 48). In a simulated context (that is, in a very specific context of the classroom [Lave and Wenger, 1991]), the text produced by the simulation is no longer followed by and connected to its appropriate uptake. Freadman argues that 
knowing a genre is also knowing how to take it up: the manners are reciprocal.... Using a text is primarily a matter of understanding its genre and the way it plays it - recognizing it, certainly, but also reading its tactics, its strategies, and its ceremonial place. Learning to write, equally, is learning to appropriate and occupy a place [italics added] in relation to other texts, learning to ensure that the other chap will play the appropriate game with you, and learning to secure a useful uptake: the rules for playing, the rules of play, and the tricks of the trade. (p. 63)

Attempts have been made "to avoid problems associated with simulations: the rhetorical confusions and the thinness of the discursive context" (Freedman \& Artemeva, 1998, p. 12); however, it remains unclear how successful acquisition of a genre by students in the classroom can be assessed, unless we agree that such an assessment becomes possible only years after the students have been involved in the interaction with a particular genre. It has been suggested (e.g., Adam \& Artemeva, 2002: Freedman \& Adam, 1996, 2000) that when determining the success of the acquisition of (written) genres, one must focus on the following areas: "the goals, authenticity, and attenuation of the writing task; the roles assumed by guides and learners; the nature of evaluation; and the sites for learning" (Adam \& Artemeva, 2002, pp. 183-184). This advice takes us well beyond the teaching and learning of textual features in a traditional classroom.

Swales (1993) stresses that it is important to pay close attention to the way genres function within systems of genres (Bazerman, 1994), in which genres coexist symbiotically "(feeding one off the other) and yet in a state of dynamic tension" (p. 692). Pedagogical implications of this view are such that the teaching of genres is only meaningful if genres are taught as systems, that is, not as separate assignments but as connected and interdependent ones, not as stabilized entities but as only stabilizedfor-now (Schryer, 1993, 1994) or, in fact, never stabilized ones (Bawarshi, 2000; Devitt, 2000). A question then arises, should we even attempt to teach genres? RGS scholars (e.g., Coe et al., 2002; Dias et al, 1999; Dias \& Paré, 2000; Freedman \& Medway, 1994a, 1994 b, and so on) argue that "writing is a by-product of other activities, a means for getting something else done" (Dias et al, 1999, p. 235). If we agree with this view, we need to find ways to engage students in tasks that require them to write in order to accomplish something, to do work. In the concluding paragraph of their book Worlds apart, Dias et al. (1999) propose:

if there is one major, obvious seeming way in which educational courses might prepare people better for the demands of writing at work, it is through constituting the class as a working group with some degree of 
complexity, continuity, and interdependency of joint activity. Such arrangements will go some way toward realizing the far richer communicative relations that contextualize writing in the workplace. (p. 235)

Another consequence of the rhetorical approach to genre is that it allows educators to treat student writing as a metagenre (Mirtz, 1997), containing features of both primary and secondary genres (Bakhtin, 1986a), and at the same time being shaped by the institutional constraints and the students' resistance to these constraints. We as educators should recognize the difference between workplace and academic writing as highlighted by numerous researchers (e.g., Beer, 2000; Dias et al., 1999; Dias \& Paré, 2000; Freedman \& Adam, 1996, 2000; Freedman et al., 1994) and start considering student writing as having "overarching purposes that mediate and influence and construct genre choices for students in ways different from professional writers" (Mirtz, 1997, p. 194).

In addition to the issues reviewed above, questions of ideology and power have come to the forefront of Rhetorical Genre Studies (e. g., Coe et al., 2002a; Paré, 2002; Schryer, 2000, 2002). As Devitt (2000) puts it, "The historical and institutional situatedness of genres makes them essentially ideological" (p. 701). Paré (2002) observes that participation in "genres situates writers in relations of power" (p. 63). In this respect, Schryer (1993) proposes that as teachers of writing we can teach students to critically examine genres as "evolving ... ideological vehicles that represent the values of certain groups" (p. 230). According to Coe (1994), generic structures contain attitudes built into them. These attitudes are "sometimes danced without conscious awareness or intent on the part of the individual using the genre" (p. 183). Paré (2002) notes that in the workplace, the routine "unfolding" of genres often makes them appear inevitable, "simply the way things are done" (p. 59). Perceived as such they can easily subvert novices joining the workplace if these novices have never experienced what it means to take a critical stance toward a genre, take a genre apart, and analyze its actions. These issues require further research.

\section{Conclusions}

In this paper I have presented an overview of the theoretical constructs of rhetorical genre studies and demonstrated that the reconception of genre, which started with Campbell and Jamieson in 1979 and continued with Miller's redefinition of genre as social action, provided a new direction for the study of genre. With the integration of key concepts developed by Bakhtin (e.g., utterance, addressivity, otherness, dialogism, chronotope), further exploration of these concepts by North American 
and Australian scholars, and the development of new theoretical constructs over the past twenty years, RGS has become a full-fledged discipline that allows us to view genres as much more than just textual forms. As Bazerman (1997) puts it,

genres are forms of life, ways of being. They are frames for social action. They are environments for learning. They are locations within which meaning is constructed. Genres shape the thoughts we form and the communications by which we interact. Genres are the familiar places we go to create intelligible communicative action with each other and the guideposts we use to explore the unfamiliar. (p. 19)

The overview of the recent developments in RGS has demonstrated that genre possesses the transformational force that turns "general discourse into a socially recognized and meaningful text" (Bawarshi, 200o, p. 349). Genre does not simply communicate meanings; rather, it mediates and maintains these meanings. As I have indicated in the review presented in the paper, genres are "inherently open-ended rather than complete wholes" (Hanks, 1987, p. 677) that shape rhetors as much as rhetors shape genres (Hanks, 1987; Schryer, 2000, 2002).

The current developments in RGS focus predominantly on the refinement of our understanding of genre as a regulated and at same time improvisational and flexible communication strategy and on its temporal aspect. RGS has proved to be a very powerful tool not only in the analysis of workplace and academic genres and systems of genres but also in indicating and unpacking differences between academic and workplace communication practices.

It is important to note that RGS has been developed and used in conjunction with other rhetorical, psychological, and social theories, such as activity theory (Engeström, 1987; Leont' ev, 1981; Wertsch, 1981), theories of situated learning (Lave \& Wenger, 1991) and distributed cognition (Hutchins, 1995), and social theories of practice by Bourdieu (Harker, Mahar, \& Wilkes, 1990) and Wenger (1999). At present, it is difficult to find a study that would rely on RGS as its sole theoretical framework, as it has been demonstrated (e.g., Paré, 2000; Schryer, 2000) that complementary theories provide further insight into the questions RGS attempts to answer. In addition to its significant theoretical contribution to the modern understanding of human communication, RGS used in combination with complementary theories has important pedagogical implications. The rhetorical view of genre that serves as the basis of Rhetorical Genre Studies allows educators to reconceptualize their understanding of what makes communication effective and what is and is not possible to teach in an academic classroom. 


\section{Notes}

'Rhetorical Genre Studies is a term coined by Aviva Freedman (1999, 2001). RGS is also known as North American genre theory.

${ }^{2}$ I have emphasized the term "constellation" used by Campbell and Jamieson because this term later becomes a cornerstone of Schryer's revised definition of genre $(2000,2002)$. Schryer's definition is discussed later in this paper.

${ }^{3}$ Curiously, M. Holquist (1990) asserts that "dialogism" is "a term ... never used by Bakhtin himself" (p. 15), while I have observed that, for example, in the Russian version of Problema teksta $v$ lingvistike, filologii $i$ drugih gumanitarnih naukah: Opit filosofskogo analiza [The problem of the text in linguistics, philology, and the human sciences: An experiment in philosophical analysis] (1986c) Bakhtin uses the Russian word dialogism on p. 491 and various derivatives of this word throughout the article.

${ }^{4}$ Campbell and Jamieson's definition is quoted earlier in this paper.

${ }^{5}$ This clear distinction somehow escapes M. Holquist (1990) in his book Dialogism: Bakhtin and his world, where, in a lengthy discussion of the Bakhtinian notion of time-space, Holquist treats it as if it were exactly the same as Einstein's.

${ }^{6}$ The original Russian article is attributed to $1937-1938$, while the concluding remarks are dated 1973.

${ }^{7}$ It is important to remember that "standard time measures are, of course, social constructions (as exemplified by the fact that different calendars are used in different societies) but their broad usage and intersubjective acceptance renders chronos essentially taken for granted" (Yates \& Orlikowski, 2002, p. 108).

${ }^{8}$ Please note that even though this view of genre is very close to Bakhtin's concept of addressivity, Freadman's definition of genre is not the same as Bakhtin's (1986a). Bakhtin defines genres as relatively stable types of utterances, where each utterance is limited by its boundaries. The boundaries, in turn, are defined by the change of speaking subjects. Freadman's view of genre differs from Bakhtin's in that she sees two related utterances produced by different speaking subjects as one genre (1994; 2002). (I would like to thank Aviva Freedman for pointing out this distinction for me). 
${ }^{9}$ The only English translation of the Russian article (1930/2000) that I was able to locate was the 1983 abridged translation. The parts of the article omitted from the abridged edition are translated into English and reproduced in Parrot (1984).

10 "The prescriptivism and the implicit static vision of genre" (Freedman \& Medway, 1994c) represents the most significant difference between the North American (RGS) and Australian ("the Sydney School") approaches to genre pedagogy.

\section{References}

Adam, C., \& Artemeva, N. (2002). Writing instruction in English for Academic Purposes (EAP) classes: Introducing second language learners to the academic community. In A. Johns (Ed.), Genre in the classroom: Multiple perspectives (pp. 179-196). Mahwah, NJ: Erlbaum.

Artemeva, N. (1998). Writing consultant as cultural interpreter: Bridging different cultural perspectives on the genre of periodic engineering report. Technical Communication Quarterly, 7 (3), 285-299.

Artemeva, N. (2000). Revising a research article: Dialogical negotiation. In P. Dias \& A. Paré (Eds.), Transitions: Writing in academic and workplace settings (pp. 183-197). Cresskill, NJ: Hampton.

Artemeva, N., \& Freedman, A. (2001). 'Just the boys playing on computers': An activity theory analysis of differences in the cultures of two engineering firms. Journal of Business and Technical Writing, 15 (2), 164-194.

Bakhtin, M. M. (1981). Forms of time and of the chronotope in the novel: Notes towards a historical poetics. In M. Holquist (Ed.), C. Emerson \& M. Holquist, (Trans.). The dialogic imagination: Four essays by M. M. Bakhtin (pp. 84-258). Austin: University of Texas Press.

Bakhtin, M. M. (1986a). The problem of speech genres. In C. Emerson \& M. Holquist (Eds.), V. W. McGee (Trans.), Speech genres and other late essays (pp. 60-102). Austin, TX: University of Texas Press.

Bakhtin, M. M. (1986b). The Bildungsroman and its significance in the history of realism (toward a historical typology of the novel). In C. Emerson and $M$ Holquist (Eds.), V. W. McGee (Trans.), Speech genres and other late essays (pp. 10-59). Austin, TX: University of Texas Press. 
Bakhtin, M. M. (1986c). Problema teksta v lingvistike, filologii i drugih gumanitarnih naukah: Opit filosofskogo analiza [The problem of the text in linguistics, philology, and the human sciences: An experiment in philosophical analysis]. In M. M. Bakhtin, Literaturno-kriticheskiyi statii [Articles on literary criticism] (pp. 473-500). Moscow: Khudojestvennaya Literatura.

Barabas, C. (1990). Technical writing in a corporate culture: A study of the nature of information. Norwood, NJ: Ablex.

Bawarshi, A. (2000). The genre function. College English, 62 (3), 335-36o.

Bazerman, C. (1994). Systems of genres and the enactment of social intentions. In A. Freedman \& P. Medway (Eds.), Genre and the new rhetoric, (pp. 79-101). London: Taylor \& Francis.

Bazerman, C. (1997). The life of genres, the life in the classroom. In W. Bishop \& H. Ostrom (Eds.), Genre and writing: Issues, arguments, alternatives, (pp. 19-26). Portsmouth, NH: Boynton/Cook.

Bazerman, C. (2002). Genre and identity: Citizenship in the age of the Internet and the age of global capitalism. In R. Coe, L. Lingard, \& T. Teslenko (Eds.), The rhetoric and ideology of genre (pp. 13-37).Cresskill, NJ: Hampton Press.

Beer, A. (2000). Diplomats in the basement: Graduate engineering students and intercultural communication. In P. Dias \& A. Paré (Eds.), Transitions: Writing in academic and workplace settings (pp. 61-88). Cresskill, N. J.: Hampton Press.

Berkenkotter, C. and Huckin, T. N. (1993). Rethinking genre from a sociocognitive perspective. Written communication, 10 (4), 475-509.

Berkenkotter, C., \& Huckin, T. N. (1995). Genre knowledge in disciplinary communication: Cognition/culture/power. Hillsdale, NJ: Lawrence Erlbaum Associates.

Bitzer, L. F. (1968). The rhetorical situation. Philosophy and Rhetoric, 1, 1-14.

Bruffee, K. A. (1986). Social construction, language, and the authority of knowledge: A bibliographical essay. College English, 48, 773-79o.

Burke, K. (1957). The philosophy of literary form. New York: Vintage. 
Campbell, K. K., \& Jamieson, K. H. (1979). Form and genre in rhetorical criticism: An introduction. In K. K. Campbell \& K. H. Jamieson (Eds.), Form and genre: Shaping rhetorical action (pp. 9-32). Falls Church, VA: Speech Communication Association.

Coe, R. M. (1994). 'An arousing and fulfillment of desires': The rhetoric of genre in the process era - and beyond. In A. Freedman \& P. Medway (Eds.), Genre and the new rhetoric (pp. 181-190). London: Taylor \& Francis.

Coe, R. M. (2002). The new rhetoric of genre: Writing political briefs. In A. Johns (Ed.), Genre in the classroom: Multiple perspectives (pp. 197-207). Mahwah, NJ: Erlbaum.

Coe, R. M., \& Freedman, A. (1998). Genre theory: Australian and North American approaches. In M. L. Kennedy (Ed.), Theorizing composition: A critical sourcebook of theory and scholarship in contemporary composition studies (pp. 136-147). Westport, CT: Greenwood Press.

Coe, R., Lingard, L., \& Teslenko, T. (Eds.). (2002a). The rhetoric and ideology of genre. Cresskill, NJ: Hampton Press.

Coe, R., Lingard, L., \& Teslenko, T. (2002b). Genre, Strategy, and Differance: An introduction. In R. Coe, L. Lingard, \& T. Teslenko (Eds.), The rhetoric and ideology of genre (pp. 1-10).Cresskill, NJ: Hampton Press.

Cooper, M. M. (1989). The ecology of writing. In M. M. Cooper \& M. Holzman (Eds.), Writing as Social Action (pp. 1-13). Portsmouth, NH: Boynton/Cook Heinemann.

Cooper, M. M., \& Holzman, M. (Eds.). (1989). Writing as Social Action. Portsmouth, NH: Boynton/Cook Heinemann.

Devitt, A. J. (1991). Intertextuality in tax accounting: Generic, referential, and functional. In C. Bazerman \& J. Paradis (Eds.), Textual Dynamics of the Professions (pp. 36-357). Madison, WI: University of Wisconsin Press.

Devitt, A. J. (1996). Genre, genres, and the teaching of genre. College Composition and Communication, 47 (4), 605-615.

Devitt, A. J. (2000). Integrating rhetorical and literary theories of genre. College English, 62 (6), 696-717. 
Dias, P., Freedman, A., Medway, P., \& Paré, A. (1999). Worlds apart: Acting and writing in academic and workplace contexts. Mahwah, NI: Lawrence Erlbaum Associates.

Dias, P., \& Paré, A. (Eds.). (2000). Transitions: Writing in academic and workplace settings. Cresskill, NJ: Hampton.

Doherty, M. (n. d.). Kairos: Layers of Meaning. Kairos: A Journal For Teachers of Writing in Webbed Environments. Retrieved April 16, 2992, from http:// english.ttu.edu/kairos/layers/start.html

Faigley, L. (1995). Nonacademic writing: The social perspective. In L. Odell \& D. Goswami (Eds.), Writing in nonacademic settings (pp. 231-247). New York: The Guilford Press.

Flower, L. (1994). The construction of negotiated meaning: A social cognitive theory of writing. Carbondale: Southern Illinois University Press.

Freadman, A. (1994). Anyone for tennis? In A. Freedman \& P. Medway (Eds.), Genre and the new rhetoric (pp. 43-66). London: Taylor and Francis. (Original work published in 1987).

Freadman, A. (2002). Uptake. In R. Coe, L. Lingard, \& T. Teslenko (Eds.), The rhetoric and ideology of genre (pp. 39-53). Cresskill, NJ: Hampton Press.

Freedman, A. (1993). Show and tell? The role of explicit teaching in the learning of new genres. Research in the teaching of English, 27 (3), 222-251.

Freedman, A. (1994). 'Do as I say': The relationship between teaching and learning new genres. In A. Freedman \& P. Medway (Eds.), Genre and the new rhetoric (pp. 191-210). London: Taylor \& Francis.

Freedman, A. (1999). Beyond the text: Towards understanding the teaching and learning of genres. TESOL Quarterly, 33 (4), 764-767.

Freedman, A. (2001). Catching the wave: Rhetorical genre studies in 2001. Paper presented at the International, Interdisciplinary Conference "Genre 2001: Genres and Discourses in Education, Work and Cultural Life: Encounters of Academic Disciplines on Theories and Practices," Oslo University College, Oslo, Norway.

Freedman, A., \& Adam, C. (1996). Learning to write professionally: "Situated learning" and the transition from university to professional discourse. Journal of Business and Technical Communication, 10 (4), 395-427. 
Freedman, A., \& Adam, C. (2000). Write where you are: Situating learning to write in university and workplace settings. In P. Dias \& A. Paré (Eds.), Transitions: Writing in academic and workplace settings (pp. 31-60). Cresskills, NJ: Hampton.

Freedman, A., Adam, C., \& Smart, G. (1994). Wearing suits to class: Simulating genres and simulations as genre. Written Communication, 11 (2), 193-226.

Freedman, A., \& Artemeva, N. (1998). Learning to teach writing to engineers. Technostyle, 14 (1), 1-20.

Freedman, A., \& Medway, P. (Eds.). (1994a). Learning and teaching genre. Portsmouth, NH: Boynton/Cook.

Freedman, A., \& Medway, P. (Eds.). (1994b). Genre and the new rhetoric. London: Taylor \& Francis.

Freedman, A., \& Medway, P. (1994c). Locating genre studies: Antecedents and prospects. In A. Freedman \& P. Medway (Eds.), Genre and the new rhetoric (pp. 1-20). London: Taylor \& Fancis.

Hanks, W. F. (1987). Discourse Genres in a Theory of Practice. American Ethnologist, 14 (4), pp. 668-692.

Harker, R., Mahar, C., \& Wilkes, C. (Eds.). (1990). An introduction to the work of Pierre Bourdieu. London: Macmillan.

Harris, J. (1989). The idea of community in the study of writing. College Composition and Communication, 40 (1), 11-22.

Herrington, A. J. (1985). Classrooms as forums for reasoning and writing. College Composition and Communication, 36 (4), 404-413.

Holquist, M. (Ed.). (1981). The dialogic imagination: Four essays by M. M. Bakhtin. C. Emerson \& M. Holquist (Trans.). Austin: University of Texas Press.

Holquist, M. (1990). Dialogism: Bakhtin and his world. New York: Routledge.

Hunt, R. (1994). Speech genres, writing genres, school genres, and computer genres. In A. Freedman \& P. Medway (Eds.), Learning and teaching genre (pp. 243262). Portsmouth, NH: Boynton/Cook.

Hutchins, E. (1995). Cognition in the wild. Cambridge, Mass.: The MIT Press.

Jamieson, K. M. (1975). Antecedent genre as rhetorical constraint. Quarterly Journal of Speech, 61, 406-415. 
Lave, J., \& Wenger, E. (1991). Situated learning: Legitimate peripheral participation. Cambridge: Cambridge University Press.

Lave, J., \& Wenger, E. (1996). Practice, person, social world. In H. Daniels (Ed.), An introduction to Vygotsky (pp. 143-150). New York, NY: Routledge.

Miller, C. (1984). Genre as social action. Quarterly Journal of Speech, 70, 151-167.

Miller, C. (1992). Kairos in the rhetoric of science. In S. P. Witte, N. Nakadate, \& R. D. Cherry (Eds.), A rhetoric of doing: Essays on written discourse in honor of James L. Kinneavy (pp. 310-327). Carbondale: Southern Illinois University Press.

Miller, C. (1994a ). Genre as social action. In A. Freedman \& P. Medway (Eds.), Genre and the new rhetoric (pp. 23-42). London: Taylor \& Francis. (Original work published in 1984).

Miller, C. (1994b). Rhetorical community: The cultural basis of genre. In A. Freedman \& P. Medway (Eds.), Genre and the new rhetoric (pp. 67-78). London: Taylor \& Francis.

Mirtz, R. M. (1997). The territorial demands of form and process: The case for student writing as a genre. In W. Bishop \& H. Ostrom (Eds.), Genre and writing: Issues, arguments, alternatives (pp. 190-198). Portsmouth, NH: Boynton/Cook.

Mohawk College (n. d.). Definition of Kairos. Retrieved April, 16, 2003, from Mohawk College, Language Studies Department Web site: http:// spin.mohawkc.on.ca/ls/define.html

Paradis, J., Dobrin, D., \& Miller, R. (1995). Writing at Exxon ITD: Notes on the writing environment of an R\&D organization. In L. Odell \& D. Goswami (Eds.), Writing in non-academic settings (pp. 281-307). New York: Guiford Press.

Paré, A. (2000). Writing as a way into social work: Genre sets, genre systems, and distributed cognition. In P. Dias \& A. Paré (Eds.), Transitions: Writing in academic and workplace settings (pp. 145-166). Cresskill, NJ: Hampton.

Paré, A. (2002). Genre and identity: Individuals, institutions, and ideology. In R. Coe, L. Lingard, \& T. Teslenko (Eds.), The rhetoric and ideology of genre (pp. 57-71). Cresskill, NJ: Hampton Press. 
Paré, A., \& Smart, G. (1994). Observing genres in action: Towards a research methodology. In A. Freedman and P. Medway (Eds.), Genre and the new rhetoric (pp. 146-155). London: Taylor \& Francis.

Parks, S., \& Maguire, M. H. (1999). Coping with on-the-job writing in ESL: A constructivist-semiotic perspective. Language Learning, 49 (1), 143-175.

Parrott, R. (1984). (Re) capitulation, parody, or polemic? In B. A. Stolz, I. R. Titunik, \& L. Doleézel (Eds.), Language and literary theory: In honor of Ladislav Matejka (pp. 463-488). Ann Arbor, MI: University of Michigan.

Reither, J. (1985). Writing and knowing: Redefining the writing process. College English, 47 (6), 620-628.

Rorty, R. (1979). Philosophy and the mirror of nature. Princeton: Princeton University Press.

Russell, D. (1997). Rethinking genre in school and society: An activity theory analysis. Written Communication, 14 (4), 504-554.

Schryer, C. (1993). Records as genre. Written Communication, 10 (2), 200-234.

Schryer, C. F. (1994). The lab vs. the clinic: Sites of competing genres. In A. Freedman, \& P. Medway (Eds.), Genre and the new rhetoric (pp. 105-124). London: Taylor \& Francis.

Schryer, C. F. (1995, May). Advocacy communication: A case study of ideology, power, and culture. Paper presented at the annual conference of the Canadian Association of Teachers of Technical Writing, Montreal, Canada.

Schryer, C. (1999). Genre time/space: Chronotopic strategies in the experimental article. Journal of Advanced Composition, 19 (1), 81-89.

Schryer, C. F. (2000). Walking a fine line: Writing negative letters in an insurance company. Journal of Business and Technical Communication, 14 (4), 445-497.

Schryer, C. F. (2002). Genre and power: A chronotopic analysis. In R. Coe, L. Lingard, \& T. Teslenko (Eds.), The rhetoric and ideology of genre (pp. 73-102). Cresskill, NJ: Hampton Press.

Schryer, C. F. (2003, March 19). Genre and techne in medical case presentations. Paper presented at the Conference of College Composition and Communication, New York, USA. 
Schryer, C. F., Lingard, L., \& Spafford, M. (2003). Structure and agency in medical case presentations. In C. Bazerman \& D. Russell (Eds.), Writing selves/writing societies: Research from activity perspectives. Perspectives on Writing. Fort Collins, Colorado: The WAC Clearinghouse and Mind, Culture, and Activity. ISBN 0-9727023-1-8. Available at http://wac.colostate.edu/books/ selves_societies/

Sessions, W. L. (1995). Tillich, Paul. In Robert Audi (Ed.), The Cambridge dictionary of philosophy (p. 803). Cambridge: Cambridge University Press.

Smart, G., \& Brown, N. (2002). Learning transfer or transforming learning?: Student interns reinventing expert writing practices in the workplace. Technostyle, 18 (1), 117-141.

Swales, J. (1993). Genre and engagement. Revue Belge de Philologie et d'Histoire, 71 (3), 687-698.

Swales, J. (1990). Genre analysis: English in acadernic and research setting. Cambridge: Cambridge University Press.

Voloshinov, V. N. (1983). Literary stylistics: The construction of the utterance. In A. Shukman (Ed.), N. Owen (Transl.). Bakhtin School Papers (pp. 114-138). Oxford: RPT Publications (abridged). (Original work published in 1930).

Voloshinov, V. N. (2000). Stilistika khudojestvennoy rechi: Konstruktsia viskazivaniya [Literary stylistics: The Construction of the Utterance]. In I. V. Peshkov (Ed.), M. M. Bakhtin (behind the mask) (In Russian) (pp. 535-556). Moscow: Labirint. (Original work published in 1930).

Wenger, E. (1999). Communities of practice: Learning, meaning, and identity. Cambridge, UK: Cambridge University Press.

Wertsch, J. V. (Ed.). (1981). The concept of activity in Soviet psychology. Armonk, NY: M. E. Sharpe.

Williams, R. (1976). Keywords: A vocabulary of culture and society. London: Fontana/ Croom Helm.

Yates, J.-A., \& Orlikowski, W. (2002). Genre systems: Chronos and kairos in communicative interaction. In R. Coe, L. Lingard, \& T. Teslenko (Eds.), The rhetoric and ideology of genre (pp. 103-121).Cresskill, NJ: Hampton Press. 